\title{
$\left[\begin{array}{ll}91 & {[}\end{array}\right.$
}

\section{A Petition of the City of Winchefter to King Henry VI. Communicated by Dr. Ducarel.}

Read at the Society of Antieuaries, March I3, I755.

\section{Anno r $450.30 \mathrm{Hen}$. VI.}

To the Kynge our Soverayne Lord,

$12 \mathrm{ESECHESS}$ fulle humblie your humble trew leige men, 3 the maire, balifs, and comonalitie of your pouere citee of Wyncheftre, that, whereas they have ben charged to bere the fee ferme of your faid citee, whiche draweth yerlyee to the fomme of an cxii marc, and bere alfo to the maifter of the Hofpitalle of Marie Maudalene befide Wyncheftre $1 \mathrm{x}$ s. alfo when the $\mathrm{xv}$ penny or taxe is graunted to your highnelfe, it draweth to the fomme of li l. $x s$. iv $d$. withyne the faid citee, the whiche whenne it is levable, fum oon man in the faid citee is fette unto iii marc, and fum $v$ marc, becaufe your faid citee is defolate of peple; alfo expens of Burges of the faid citee comyng to your parlements, draweth to iiil $s$. by the daye, for the which faid fee ferme fo to be paid, your bailiffs have little or nought of cerigntee to arayfe it of but conly of cafualtees and yerelie lefen in paymente of the faid fee ferme $x 1 \%$ or more; for which caufes above faid, and alfo-for the grete charges and dayelie coltes the which your faid pouere citee berethe abowte the enclofyng and meerage of your faid citee, it is become right defolate, in fo much as many notable parfons ben withdeawen out of the faid citee for the cautes above faid, and ix mins and xrii (i. e. 997) hones, which, were wont to be occupied with peple ftondene now voide, and bycaufe of thele withedrawynge xvii paryshe churches ftond inofficiate 


\section{Petition of the City of. Winchester.}

att this day, the whiche parifhes and houfes be more plainly expreffed in a fedule hereto annexed. And where it pleafed your highnefle in relyvyng of your faid pouere citee, the xxiiiith day. of May, the yere of your regne the xix, to graunt unto your maire and commonalite of the faid citee thenne beyng in. relife of all the charges abovefaid $\mathrm{xl}$ marc, to be taken yerely to theyme and to their fucceffors unto the end of . . . wynter thenn next following offe the feftes of Eftren and Michaelmeffe by evyn porc... yons, of the iffues and prefits comyng of the ulnage and fubfidue of wollen clothes withynne the faid citee and fuburbs and foke. of the fame, and in all other places within your fhire of Suthitn by the the hands of the collectors, farmers, receyvours and other: occupiers of the fame, for the time beyng, as in your letters patents: thereof to theyme made may appear more playnlie: Which annuyte is now voyde to theym, and hoolye refumed to you, becaufe of an Acte made in your Parliament, begonne at Weftmynfter and fynesfhed at Leicefter. And fo now your faid fuppleants ftond alle. uterelie deftitute of alle manere of relife of theyre charges abovefaid, to the utterifte undoyng of your faid citee for ever; without. your high and noble grace be thewede to theym in this behalfe. That it pleefe your faid highneffe gratioufly to confidre the charges sbovefaid, and, of your moft habundant grace, to graunt unto the maire, bailifss, and commonalite of your faid citee $\mathrm{xl}$ marc $\mathrm{s}_{\text {. }}$ to be hadde and caken yerelie to theyme, and to their fucceffors, from the fere of Michaelmefs in they ere of your reigne xxviii, for evermore, of the ulnage and fubridie of wollen clothes to be fold withyn your faid citee, fuburbs and foke of the fame, and in other places withynn your mire of Sutht. by the hands of the colletors, fermours, receyvours and occupiours of the faid ulnage and fontidie for the time beying, at the fefts of Eftrenn and Whichinas by evyn porcyons after the teur and effecte of another fedule, to this bille annexed; the which fedule begynneth with thate words, "Rex omnibus ad quos," without any fine or fee in any wite to your ufe to be taken and paid, the faid aet of re: a fumption, 
fitmption or any other ftatutes, ordinances, provifions, reftreỹtes, acts, or any manere juggements, or affignements, in any wife: made or to be made, nottewitheftondyng: And thei be, and thalbe perpetuallie your oratours.

THEsE ben the ftretes that be fallen downe in the citee of Wynchẹftre withynne iiii ${ }^{x x}$ (i. e. 80) yere laft paffed.

Firft, Juriftrete, wherynne were iiii ${ }^{\times \times}(80)$ houfeholders, and: now but ii.

Item, Flefhmonger ftrete, wherynne were viix ${ }^{x x}(140)$ houfclders, and now but ii.

Item, Finmongers-ftrete, wherynne were $\mathrm{lx}$ houfeholders, and now ben but iiii.

Item, Colebroke-ftrete, wherynne: were viii houfeholders, and now ben but $\mathrm{xvi}$.

Item, Calpe-ftrete, wherynne. were $c$ houholders, and now ben but vi.

Item, Golde-ftrete, wherynne were vii ${ }^{3 \times}$ houtholders, and now ben but viii.

Item, Burden-ftrete, wherynne were $\mathrm{lx}$ hounholders, and now is never oon.

Item, Shulworth-ftrete, wherynne were $1 \mathrm{xx}$ houfholds, and and now ben but iiii.

Item, Bukles-firete, wherynne were $x 1$ houholds, and now ben but ii.

Item, Mynefire-ftrete, wherynne where $\operatorname{iii}^{\mathrm{zx}}$ and $\mathrm{x}$ hourholdes, and now ben but iiii.

Item, Gar-ftrete, wherynne were c houfholdes, and now is never oon.

THE numbre of houfholdes that ben fallen ix ${ }^{c}$ iiilix xvii (997), and without theife ben fallen withynne the fame citee, fothe the laft parlement holden there, inisx houholdes and oon. 
94 Petition of the City of Winchester.

ThEISE ben the parifhe churches that ben.fallen downe within the faid citee,

The chirch of Saint Saviour $\}$ in Burden-ftrete.

The chirch of Saint Michael, in Juri-ftrete.

$\left.\begin{array}{l}\text { The chirch of Saint Michael, } \\ \text { The chirch of Saint Swithin, }\end{array}\right\}$ in Flefhmonger-ftrete.

'The chirch of Saint Martin, in Parifhment-ftrete.

The chirch of Saint Swithin, in Shulworth-ftrete.

The chirch of Saint Johan de Port Latyne, in Bukke-ftrete.

'The chirch of Saint Martine, in Myneftre-ftrete.

$\left.\begin{array}{l}\text { The chirch of Saint Alphege, } \\ \text { The chirch of Saint Petrok, }\end{array}\right\}$ in Calpe-ftrete:

The chirch of Saint Nicolas, 3 in Golde-ftrete.

The chirch of Saint Margaret,

$\left.\begin{array}{l}\text { The chirch of Saint Andrewe, } \\ \text { The chirch of Saint Poule, }\end{array}\right\}$ in Gar-ftrete.

The chirch of Saint Johan in the Joye, in Tanner-ftrete.

The numbre xvii cherches.

THE defolation of the faid pouere citee is fo grete, and yerelie fallyng, for there is fuche decaye and unwyne, that, without gracious comforte of the Kyng our foverayne lord, the mair and the bailiffs mult of neceffitee ceffe and deliver uppe the citee and the kayes into the Kynges hands.

Mlem. "Quod primo die Febr. anno regni Regis Henr. vi, "poft conqueftum tricefimo, ifta billa liberata fuit Domino Can"cellario Angliae, apud Weftm. exequend.

" REx omnibus ad quos, \&c. falutem. Sciatis quod de gratia " noftra feciali, ceiterifque notabilibus canfis nos fpecialiter moven"tibus, dedimus et conceffmus, ac per prefentes damus et conce.6 dimus 
"dimus, dilectis nobis, majori, ballivis, et communitati civitatis "Winton, quadraginta marcas habend. et percipiend. annuatim, " prefatis majori, ballivis et co"itati, ac fuccefforibus fuis, civibus “6 dicte civitatis, de exitibus, firmis, et proficuis de ulnagio et fubfidio " per annorum venalium infra dictam civitatem et fuburbia ejufdem, " ac infra fokam ibidem, ac alibi infra Com. Suth. provenientibus " per manus collectorum, firmariorum, receptorum feu occupatorum " ulnagii et fubfidii predict. pro tempore exiften. ad terminos Pafche " et Sancti Michaelis per equales porcóes, eo quod expreffa mentio "de aliis donis et concefilonibus eifdem, majori, ballivis et com" munitati aut predecefforibus, frve àntecefforibus fuis, et eorum "fuccefforibus, per nos aut aliquem progenitorum noftrorum re"gum Anglie ante hec tempora habitis, five factis prefentibus; "facta non exiftet, aut aliquibus ftatutis, ordinationibus, provifioni" bus, refumptionibus, frive actibus quibufeunque ante hec tempora " quovis modo fact. ordin at. provif. five habita, aut aliquo fta" tuto, ordinatione, provifione, refumptione, five actu quocunque " ante hec tempora, aliquo modo fact. ordinat. provif. five habit. " aut aliqua alia caufa, materia, five alia re quacunque non obftant. "In cujus rei, \&ac. Tefte, \& c.

"Dat. apud Weftm. le xxviii jour de: "Janvier, l'an, 8xc. tricefimo."

ThE King hath graunted this bille for the terme of 1 yeres next: comyng, under fuch forme, as he, by his other letters patents, graunted the fame herbefore. Prefent my lords of Wynchefter and Somerfet.

JoSEPH. 